\title{
Inefisiensi Pengadaan Tanah untuk Kepentingan Umum
}

\section{Inefficiency of Land Procurement for Public Interest}

\author{
Idah Wahidah \\ Universitas Islam Negeri (UIN) Sunan Gunung Djati Bandung \\ Jl. A.H. Nasution No. 105 Kota Bandung 40614, Indonesia \\ *corresponding author E-mail: Idah.wahidah91@gmail.com
}

Diterima: 15 Juni 2019; Direvisi: 25 Juni 2019; Disetujui: 5 Juli 2019

\begin{abstract}
ABSTRAK
Pembangunan Bendungan Jatigede untuk kepentingan umum tidak seimbang dalam implementasinya. Berdasarkan hasil pengamatan, peneliti melihat banyak masalah yang terjadi, termasuk pembebasan lahan mengeluarkan banyak regulasi, implementasinya cukup panjang, dan biaya yang dikeluarkan cukup besar. Peneliti menggunakan teori E. Bardach, untuk menentukan operabilitas administratif (otoritas, komitmen institusional, kapabilitas, dukungan organisasi) kriteria, untuk mengetahui dampak dari peneliti kebijakan menggunakan teori Thomas R. Dye. Metode dan pendekatan penelitian dilakukan dengan metode penelitian kualitatif dan kuantitatif dengan pendekatan deskriptif. Metode pengumpulan data adalah melalui observasi, wawancara terstruktur dan dokumentasi. Teknik pemilihan informan menggunakan teknik purposive dan validitas data dengan triangulasi data. Hasil penelitian ini menggunakan pendekatan kriteria operabilitas administratif tidak memenuhi kriteria secara optimal.
\end{abstract}

Kata kunci : Kriteria Evaluasi Kebijakan, Evaluasi Dampak Kebijakan, Ketidakefisienan, Pengadaan Tanah, Waduk Jatigede

\section{ABSTRACT}

The construction of the Jatigede Dam for the public interest is imbalanced in its implementation. Based on the results of observations, researchers see a lot of problems that occur, including land acquisition issued a lot of regulations, implementation is quite long, and the costs incurred are quite large. The researcher uses E. Bardach's theory, to determine administrative operability (authority, institutional commitment, capability, organizational support) criteria, to find out the impact of policy researchers using the theory of Thomas $R$. Dye. Research methods and approaches are carried out with qualitative and quantitative research methods with a descriptive approach. The method of data collection is through observation, semistructured interviews and documentation. The informant selection technique uses purposive techniques and the validity of the data by data triangulation. The results of this study using the administrative operability criteria approach did not meet the criteria optimally.

Keywords: Policy Evaluation Criteria, Policy Impact Evaluation, Inefficiency,

POLITICON VOL.1 No.1 Juli 2019 
POLITICON : Jurnal Ilmu Politik Vol.1 No.1 ; Hal 51 - 71

Website : http://journal.uinsgd.ac.id/index.php/politicon

ISSN : 2685-6670 ( Online )

Land Acquisition, Jatigede Reservoir

\section{PENDAHULUAN}

Pengadaan tanah saat ini salah satunya di Indonesia adalah Pembangunan Waduk Jatigede, pembangunan waduk ini telah direncanakan sejak tahun 1963, kemudian pada tahun 1982-1986 dimulai proses penggantian kerugian pertama. Penggantian kerugian kedua dilaksanakan pada tahun 1994-1997 dan tahap ketiga pada tahun 2005-2012. Tujuan utama pembangunan waduk jatigede adalah untuk pengendalian banjir dan sarana irigasi bagi daerah hilir yang mencakup 4 Kabupaten yaitu Kabupaten Sumedang, Majalengka, Cirebon dan Indramayu. Selain itu juga sebagai pembangkit listrik tenaga air. Secara garis besar pembangunan waduk jatigede membawa implikasi penting bagi perkembangan ekonomi keempat daerah, tidak hanya berdampak terhadap ekonomi rumah tangga akan tetapi juga penduduk.

Kawasan Bendungan Jatigede Kabupaten Sumedang beroperasi pada tanggal 31 Agustus 2015, menenggelamkan 28 desa di wilayah Sumedang dan akan mengairi 90 ribu hektar lahan pertanian dengan pembangkit listrik mencapai 110 MW. Saat ini Jatigede memang telah berdiri kokoh dengan panjang bendungan 1.710 meter dan elevasi maksimal 260 meter. Proyek Jatigede sendiri telah menyebabkan pembukaan jalan pengganti mulai dari daerah Wado menuju ke daerah Darmaraja di Kabupaten Sumedang. Jalur lingkar jalanannya mencapai 15 kilometer, yang juga menimbulkan masalah baru, masalah klasik pembebasan lahan.

Tahun 1982-1986 merupakan pangkal dari masalah pembebasan lahan, lewat Peraturan Menteri Dalam Negeri Nomor 15 tahun 1975. Hal itu bisa diketahui dengan mudah apabila berpedoman pada buku kuning, sebuah buku catatan yang menjadi pegangan pemerintah setempat hingga pusat dalam memberikan penggantian lahan untuk sekitar 4.514 kepala keluarga yang berhak. Dari data yang didapatkan, sesuai dengan risalah harga penaksiran 22 Desember 1983 Nomor 34 Tahun 1983, pembayaran telah dilakukan 
POLITICON : Jurnal Ilmu Politik Vol.1 No.1 ; Hal 51 - 71

Website : http://journal.uinsgd.ac.id/index.php/politicon

ISSN : 2685-6670 ( Online )

pemerintah pusat melalui pemerintah kabupaten dan provinsi dalam rentang 1982-1986. Namun, pembangunan terhenti karena gejolak sosial politik, bahkan tawar-menawar harga saat itu tidak ada artinya, karena warga telah disodorkan harga pasti di era Soeharto. Dahulu tidak ada proses tawarmenawar, tapi memang harus ikut harga yang ditentukan. Munculnya kelompok lain diluar hasil pemetaan pemerintah melalui Bappeda yang mengaku warga sekitar namun tidak mendapatkan ganti rugi menjadi persoalan baru, hingga sampai di pembayaran berikutnya periode 1996 dan periode 2006-2009. Pengadaan tanah untuk pembangunan Waduk Jatigede bagi kepentingan umum terdapat ketidakseimbangan dalam pelaksanaannya,

1. Penyesuaian harga lahan dan bangunan yang dibebaskan atau mendapat ganti rugi tahun 1982-1986, dikarenakan terlalu rendahnya harga dan adanya pemaksaan serta intimidasi dalam pembebasan lahan dan bangunan.

2. Dalam pembayaran ganti rugi terdapat masyarakat (pemilik lahan) yang merasa belum menerima uang pembebasan ganti rugi, yang menerima uang pembebasan ganti rugi bukan pemilik lahan tetapi kepala desa atau orang lain.

3. Salah pengukuran lahan yaitu lahan dan bangunan yang dibebaskan atau mendapat ganti rugi luasnya lebih kecil dibandingkan luas lahan yang sebenarnya, pada saat pengukuran oleh petugas warga tidak dilibatkan.

Sehingga pemerintah pusat dan provinsi menggelontorkan uang lebih banyak, dikarenakan jumlah pengaduan yang diterima BPKP Jabar mencapai belasan ribu yang terdiri dari 407 aduan atas penyesuaian harga dan bangunan tahun 1982-1986 dari aturan SK Bupati dan SK Dirjen Bina Marga. Selain itu, ada pengaduan lainnya sebagai berikut:

Tabel 1. Data Pengaduan

\begin{tabular}{|c|c|c|}
\hline Jenis Pengaduan & Jumlah Pengaduan & $\%$ \\
\hline 1. Salah Pembayaran & 7 & 0.06 \\
\hline $\begin{array}{l}\text { 2. Salah pengukuran dalam } \\
\text { pembebasan lahan }\end{array}$ & 5.687 & 48.5 \\
\hline 3. Salah klasifikasi & 2.024 & 17.3 \\
\hline & 3.646 & 31.1 \\
\hline
\end{tabular}


POLITICON : Jurnal Ilmu Politik Vol.1 No.1 ; Hal 51 - 71

Website : http://journal.uinsgd.ac.id/index.php/politicon

ISSN : 2685-6670 ( Online )

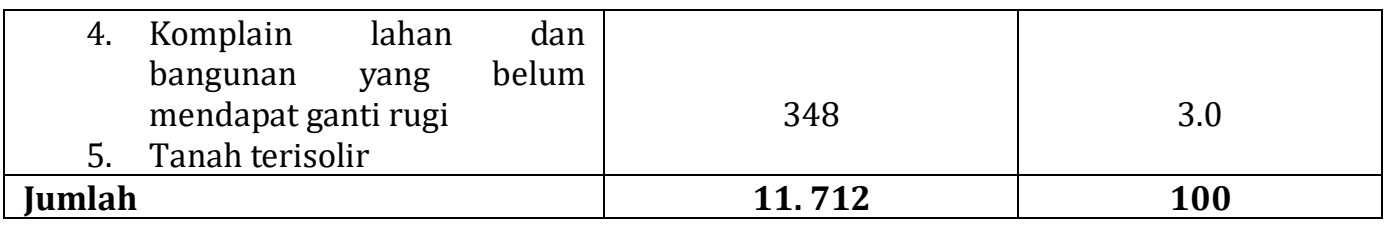

Sumber: diolah peneliti dari berita tentang data pengaduan masyarakat penerima ganti rugi pembangunan Waduk Jatigede.

Selain permasalahan diatas, ada permasalahan lain sejak tahun 2006, kemunculan rumah-rumah baru tak berpenghuni yang sengaja dibangun agar masuk hitungan penggantian. Masalah itu menjadi perdebatan dan ditinggalkan sejak 2010, namun menyisakan pilu bagi warga yang berhak mendapatkan ganti rugi, karena alokasi pembayaran tiba-tiba hilang diambil pemilik rumah baru ilegal yang dicatat pemerintah daerah berhak mendapat penggantian. Melihat gundukan masalah yang masih terlampau menggunung, Bendungan Jatigede seolah menjadi pertaruhan bagi pemerintah. Proses ganti rugi yang dilakukan untuk pembangunan waduk jatigede memakan waktu yang cukup lama dari tahun 1982 sampai tahun 2015 yaitu 33 tahun. Perpanjangan waktu tersebut menyebabkan pembengkakan dana APBN.

Berdasarkan latar situasi di atas maka penting untuk dicermati lebih lanjut, maka peneliti tertarik untuk menjadikan bahan penelitian mengapa terjadi inefisiensi pengadaan tanah untuk pembangunan Waduk Jatigede di Kabupaten Sumedang dan bagiamana dampak pengadaan tanah untuk pembangunan Waduk Jatigede di Kabupaten Sumedang.

\section{METODE PENELITIAN}

Metode penelitian yang digunakan dalam Inefisiensi Pengadaan Tanah untuk Kepentingan Umum (Studi Kasus Pembangunan Waduk Jatigede di Kabupaten Sumedang) adalah metode kualitatif dan kuantitatif sehingga lebih mudah memahami persoalan-persoalan dilapangan. Instrumen yang utama dalam pendekatan metode ini adalah peneliti itu sendiri, sebagai pengumpul data dan sebagai penentu dalam keseluruhan proses dari penelitian (Creswell, 2003: 21). Pemilihan metode mix method dengan alasan untuk mengetahui bagaimana efisiensi dan dampak dalam pengadaan tanah untuk pembangunan Waduk Jatigede di Kabupaten Sumedang dan merupakan 
POLITICON : Jurnal Ilmu Politik Vol.1 No.1 ; Hal 51 - 71

Website : http://journal.uinsgd.ac.id/index.php/politicon

ISSN : 2685-6670 ( Online )

sebuah fokus masalah yang abstrak dan memerlukan pencarian makna.

\section{Jenis Penelitian}

Penelitian ini menggunakan metode penelitian kombinasi (mixedmethods) yakni metode penelitian yang menggabungkan metode kualitatif dan metode kuantitatif. Metode kualitatif dan metode kuantitatif memandang bahwa suatu gejala dianggap relative tetap, tidak berubah dalam waktu tertentu. Metode kombinasi yang peneliti gunakan adalah model embedded strategy, yakni metode penelitian yang mengkombinasikan penggunaan metode kualitatif dan metode kuantitatif secara simultan (secara bersamasama), tetapi bobot metodenya berbeda, ada metode primer dan metode sekunder. Metode primer digunakan untuk data utama dan metode sekunder digunakan untuk memperoleh data guna melengkapi data yang diperoleh dari metode primer. Pada kajian ini peneliti menggunakan penelitian kualitatif sebagai metode primernya dan metode sekunder adalah penelitian kuantitatif.

\section{Sumber Data}

Sumber data yang peneliti gunakan dalam penelitian ini terbagi ke dalam dua sumber data, yaitu sumber data primer dan sumber data sekunder. Data primer adalah data yang peneliti dapatkan secara langsung melalui wawancara langsung dengan informan penelitian yaitu beberapa instansi yang terlibat dalam proses pengadaan tanah. Sementara data sekunder peneliti dapatkan dari Dokumen Pengadaan Tanah di Satker Waduk Jatigede, Website BPN, serta literature lainnya yang mendukung penelitian ini.

\section{Informan}

Sebelum melakukan wawancara di lapangan, peneliti terlebih dahulu menentukan informan melalui sebuah teknik yaitu purposive sehingga saat di lapangan, melakukan wawancara informan yang dituju diharapkan bisa mengemukakan data yang relevan dengan permasalahan penelitian. Selain menggunakan metode purposive, juga menggunakan teknik snowball. Hal ini dilakukan karena dari informan yang terpilih belum didapatkan data yang lengkap sehingga diperlukan informan-informan lainnya berdasarkan pertimbangan sejauh dan sevalid apa data yang sudah didapat. Adapun 
informan yang diwawancarai terkait penelitian ini, antara lain:

Tabel 2. Informan Penelitian

\begin{tabular}{|c|c|c|}
\hline No & $\begin{array}{l}\text { Informan } \\
\text { (Key Person) }\end{array}$ & Posisi Informan/ Status Kerja \\
\hline 1 & $\begin{array}{l}\text { epala Seksi (Kasi) Pengadaan } \\
\text { anah di BPN Kabupaten } \\
\text { umedang }\end{array}$ & Kepala Seksi \\
\hline 2 & nggota DPR RI & $\begin{array}{l}\begin{array}{l}\text { Anggot DPR RI } \\
\text { Majalengka }\end{array} \\
\end{array}$ \\
\hline 4 & epala Dinas PU & Dinas Pekerjaan Umum Kab. Sumedang \\
\hline 5 & epala Seksi & Seksi Pengadaan Tanah \\
\hline 6 & epala Seksi & $\begin{array}{l}\text { Seksi Penanganan Masalah dan Pengendalian } \\
\text { Pertanahan }\end{array}$ \\
\hline 7 & Subseksi & $\begin{array}{l}\text { Subseksi Fasilitas Pengadaan dan Penetapan Tanah } \\
\text { Pemerintah pada Dinas Pertanahan dan Tata Ruang } \\
\text { Kabupaten Sumedang }\end{array}$ \\
\hline 8 & PPK Pertanahan & $\begin{array}{l}\text { PPK Pertanahan pada Satuan Kerja Proyek Waduk } \\
\text { Jatigede }\end{array}$ \\
\hline 9 & $\begin{array}{l}\text { Satuan Kerja Proyek } \\
\text { Jatigede }\end{array}$ & Pegawai sejak Tahun 1983-Sekarang \\
\hline 10 & $\begin{array}{l}\text { Kepala Desa terkena } \\
\text { dampak pemberian ganti } \\
\text { rugi pada Pembangunan } \\
\text { Waduk Jatigede }\end{array}$ & Representasi Panitia 9 pembangunan Waduk Jatigede \\
\hline 11 & $\begin{array}{l}\text { Kepala Kecamatan Wado, } \\
\text { Darmaraja, Jatigede }\end{array}$ & Unsur Pemerintah \\
\hline 12 & Masyarakat & $\begin{array}{l}\text { Masyarakat yang mendapat ganti kerugian atas hak } \\
\text { tanahnya (OTD) }\end{array}$ \\
\hline
\end{tabular}

Sumber : Peneliti, 2017

\section{Studi Kepustakaan (Library research)}

Studi kepustakaan pada dasarnya mencari dokumen yang sesuai dengan tema penelitian. Dokumen adalah data sekunder dan informasi yang telah diolah dan diperolah dari litelatur-litelatur serta dokumen yang berkaitan dengan masalah yang dikaji, yaitu inefisiensi pengadaan tanah untuk kepentingan umum yang dengan staudi kasus pembangunan waduk Jatigede di Kab. Sumedang. Dokumen dalam hal ini berupa artikel, media, peraturan atau kebijakan, laporan, jurnal, dokumen publik, dan lain sebagainya yang memungkinkan dan bermanfaat bagi pengembangan penelitian ini. Selain sumber data diatas, peneliti juga melakukan observasi di lapangan guna untuk memperoleh data seakurat mungkin berdasarkan pengamatan yang dilakukan di lapangan. peneliti merasa lebih bisa mengeksplorasi kajian permasalahan yang sedang diteliti yaitu tentang 
POLITICON : Jurnal Ilmu Politik Vol.1 No.1 ; Hal 51 - 71

Website : http://journal.uinsgd.ac.id/index.php/politicon

ISSN : 2685-6670 ( Online )

pengadaan tanah pada pembangunan Waduk Jatigede.

\section{Analisis dan Reduksi Data}

Analisis dan interpretasi data dilakukan dengan menggunakan proses analisis menurut Miles \& Huberman, yaitu reduction data, display data, dan conclusion drawing. Ketiga proses tersebut merupakan bagian dari pendekatan kualitatif. Tahapan-tahapannya antara lain sebagai berikut (Miles \& Huberman, 1994: 10).

1. Pengumpulan data mentah.

Peneliti mengumpulkan data mentah dengan cara mencatat poin-poin penting dari hasil obesevasi awal dilapangan dan hasil penelitian lapangan, hal ini peneliti lakukan guna mempermuda peneliti untuk menganalisis hasil penelitian. Sedangkan dokumen berupa laporan pelaksanaan pengadaan tanah pada pembangunan Waduk Jatigede, jurnal ilmiah tentang pengadaan tanah dan litelatur lain yang berkaitan dengan pengadaan tanah sebagai acuan tambahan dalam menganalisis hasil penelitian.

2. Reduksi data.

Proses ini dilakukan peneliti dengan cara:

a. Melakukan seleksi data yang ketat dalam artian peneliti misasahkan antara data primer dan sekunder. Menuliskan poin-poin penting saja dari hasil observasi dan penelian dilapangan kemudian dari poin-poin penting tersebut peneliti merubah kedalam kalimat dalam bentuk paragraph sehingga mudah dipahami.

b. Mengelompokkan data berdasarkan tingkat relevansi dan kaitannya dengan setiap kelompok data yakni, Pertama:memisahkan data dari hasil penelitian dilapangan dengan dokemen yang dapatkan dari BPN Kabupaten Sumedang dan Satker Jatigede Kedua: membuat catatan khusus terkait dengan informasi yang didapatkan melalui website resmi seperti website BPN, media online maupun jurnal dan pendapat pribadi berupa tulisan di blog terkait pengadaan tanah. Ketigat: membuat catatan tambahan 
POLITICON : Jurnal Ilmu Politik Vol.1 No.1 ; Hal 51 - 71

Website : http://journal.uinsgd.ac.id/index.php/politicon ISSN : 2685-6670 ( Online )

ketika peneliti mendapatkan informasi baru yang berkaitan dengan penelitian. Keempat: peneliti melakukan analisis antar lokasi pada masing-masing kecamatan di lingkungan masyarakat yang terkena dampak.

3. Display data adalah peneliti melihat kerangka teori sebagai acuan dan melakukan pemetaan data secara manual dari data primer dan data sekunder kemudian membuat argumen dalam bentuk narasi dan dalam bentuk tabel untuk lebih mudah dipahami.

4. Penarikan kesimpulan (conclusion drawing). Peneliti melakukan interpretasi pada setiap data yang telah dikumpulkan dengan membuat kesimpulan-kesimpulan sementara dan memberikan argumen berdasarkan pada teori yang digunakan sebagai acaun penelitian. Kemudian disajikan dalam pembahasan penelitian sebagai informasi yang dapat mendukung tujuan penelitian, dan hingga pada akhir penarikan kesimpulan bahwa penelitian ini merupakan temuan baru dan belum pernah diteliti sebelumnya.

\section{Teknik Pemeriksaan Keabsahan Data}

Sebuah penelitian tentunya dibutuhkan data hasil penelitian yang memenuhi kriteria ilmiah berupa keabsahan data. Maka Peneliti melakukan pengecekan berulang kali dan memastikan data hasil penelitian agar tetap sesuai atau sejalan dengan konsep dan teori yang digunakan. Sementara itu, untuk mendapatkan validitas data dilakukan dengan menggunakan metode triangulasi (triangulate), baik dari informan, sumber data, teknik pengumpulan data, serta instrumen penelitian seperti gambaran riset di lapangan. Dan juga, peneliti perlu melakukan korespondensi dengan informan untuk meng-triangulate hasil anggapan informan yang telah ditulis. Setelah semua proses itu dilewati, data dianggap valid ketika tidak ada perbedaan antara yang dilaporkan atau ditulis oleh peneliti dengan apa yang sebenarnya terjadi pada obyek penelitian (Creswell, 2003: 196). 
POLITICON : Jurnal Ilmu Politik Vol.1 No.1 ; Hal 51 - 71

Website : http://journal.uinsgd.ac.id/index.php/politicon

ISSN : 2685-6670 ( Online )

\section{TEMUAN DAN PEMBAHASAN}

Kriteria penilaian kebijakan untuk membandingkan alternatif-alternatif dan menentukan alternatif yang paling relevan dengan kondisi yang ada. kriteria harus dapat dihitung, diatur dan memiliki standar. Kriteria evaluasi kebijakan dihasilkan dari proses. alternatif-alternatif harus didesain sehingga dapat menjadi pilihan untuk memecahkan masalah. Kriteria evaluasi penting untuk pengukuran pencapaian tujuan, untuk melakukan perbandingan, pengukuran dan pemilihan alternatif yang harus diputuskan.

Tipologi Bardach, untuk mengatur kriteria evaluasi Bardach (1972:216) memiliki batasan utama terkait administrative operability dalam penentuan sasaran pada desain kebijakan.Dalam penelitian ini penulis mencoba melakukan evaluasi kondisi masyarakat penerima ganti rugi dalam pengadaan tanah untuk pembangunan Waduk Jatigede di Kabupaten Sumedang. Berdasarkan Eugene Bardach dalam Patton Savicky dimana evaluasi kebijakan dilakukan untuk menilai sejauhmana keefektifan kebijakan publik untuk dipertanggungjawabkan kepada publiknya dalam rangka mencapai tujuan yang telah ditetapkan. Mengutip Carol H. Waiss (1989) dalam Basic Method of Policy, Analisys and Planning. Patton Savicky (1986:302) kegagalan program atau kebijakan dapat disebabkan oleh dua hal yaitu program yang tidak dapat dilaksanakan (kegagalan program) atau program yang dilaksanakan hasilnya tidak sesuai dengan yang diharapkan (kegagalan teori). evaluasi dibutuhkan untuk melihat kesenjangan antara harapan dan kenyataan. harapan semua pihak hampir sama ingin sejahtera dan dapat melakukan pekerjaan sebaikbaiknya.(Leylasari, 2015) Kriteria yang perlu dipertimbangkan dalam hal ini adalah berkaitan operasional administrasi (administrative operability), diantaranya:

\section{Authority (Kewenangan)}

Kewenangan bagi tanah yang dibebaskan melalui proses ganti rugi berdasarkan undang-undang nomor 5 tahun 1960 tentang Peraturan Dasar Pokok-pokok Agraria. Dalam ketentuan-ketentuan mengenai tata cara 
POLITICON : Jurnal Ilmu Politik Vol.1 No.1 ; Hal 51 - 71

Website : http://journal.uinsgd.ac.id/index.php/politicon

ISSN : 2685-6670 ( Online )

pembebasan tanah berdasarkan Peratuan Menteri Dalam Negeri (PERMENDAGRI Nomor 15 Tahun 1975). Untuk memenuhi kebutuhan tanah dalam usaha-usaha pembangunan, baik yang dilakukan oleh instansi/badan Pemerintah maupun untuk kepentingan Swasta, khususnya untuk keperluan Pemerintah dirasakan perlu adanya ketentuan mengenai pembebasan tanah dan sekaligus menentukan besarnya ganti rugi atas tanah yang diperlukan secara teratur, tertib dan seragam. Selama proses pengadaan tanah dari tahun 1083 sampai 2015 mengalami beberapa tahapan dan mengalami beberapa kali perubahan regulasi, sehingga berdampak pada perubahan secara kewenangan atas perubahan tersebut. Berkali-kali perubahan kewenangan secara otomatis tanggung jawab atas berlangsungnya pembangunan Waduk Jatigede sering mengalami kendala kaitan tanggung jawab kemajuan pembebasan tanah.

\section{Institual Commitment (komitmen institusi).}

Komitmen instutusi menyangkut komitmen dari adminstrator level atas dan bawah, kantor dan pekerja lapangan. Kriteria ini untuk menilai apakah suatu alternatif kebijakan bersifat realistis atau tidak. Proses pengadaan tanah pembangunan Waduk Jatigede mengalami keterlambatan dari rencana yang sudah ditetapkan sebelumnya. Terlihat dari rencana penggenangan yang terlambat sampai 1 tahun. Selain itu, banyak sekali masyarakat yang mengalami proses yang cukup panjang dan selama perjalanan yang dilaluinya selalu tidak pasti kaitan tempat dan waktu. Misalnya menentukan jadwal rapat dan tempat rapat untuk musyawaran atau negosiasi harga. Relokasi yang pemerintah janjikan kepada masyarakat tidak sesuai kesepakatan awal, sehingga pada akhirnya sebagian masyarakat yang tidak menerima memilih untuk meminta uang tunai untuk penggantinya.

\section{Capability (Kemampuan)}

Capability yaitu berkaitan dengan apakah organisasi yang akan mengimplementasikan dinilai mampu dalam konteks skills dari staf dan dalam konteks finansial. Dalam melaksanakan aktivitas kerja suatu organisasi, 
POLITICON : Jurnal Ilmu Politik Vol.1 No.1 ; Hal 51 - 71

Website : http://journal.uinsgd.ac.id/index.php/politicon

ISSN : 2685-6670 ( Online )

dibutuhkan sumber daya manusia untuk merealisasikan aktivitas kerja tersebut, artinya sumber daya manusia merupakan komponen utama dalam berjalannya suatu kegiatan organisasi. Di Kantor Satuan Kerja Waduk Jatigede memiliki sumber daya manusia yang mempunyai masing-masing tugas dan fungsi yang berguna untuk mencapai tujuan utama Kantor Satuan Kerja Waduk Jatigede.

\section{Organizational Support (Dukungan Organisasi)}

Organizational support yaitu berkaitan dengan tersedia tidaknya dukungan-dukungan peralatan, fasilitas fisik dan pelayanan-pelayanan lainnya. Berkaitan dengan dukungan tersebut, dalam proses pengadaan tanah sudah memenuhi kebutuhan. Bahkan banyak gedung khusus proyek atau pembangunan Waduk Jatigede yang ada di Sumedang selain satker pusat. Namun yang disayangkan sekarang tidak begitu dipelihara sehingga tidak terpakai lagi. Disamping itu, peralatan untuk penunjang lain dalam pengadaan tanah pun sudah memenuhi kebutuhan.

\section{Dampak Pengadaan Tanah untuk Pembangunan Waduk Jatigede di}

\section{Kabupaten Sumedang}

Berdasarkan kriteria pendekatan yang sudah dilakukan penelitian, dapat diketahui dampak dari kebijakan. Dampak kebijakan adalah keseluruhan efek yang ditimbulkan oleh suatu kebijakan dalam kondisi kehidupan nyata (Dye, 1981). Pada tahapan ini kebijakan yang telah dijalankan akan dinilai atau dievaluasi, untuk melihat sejauhmana kebijakan yang dibuat telah mampu memecahkan masalah. Kebijakan publik pada dasarnya dibuat untuk meraih sebuah hasil yang diinginkan. Dalam hal ini, memecahkan masalah yang dihadapi masyarakat berdasarkan skala prioritas yang dianggap paling urgens. Berdasarkan hasil penelitian Buchari. A., Sumaryana, A., dan Novi. AR., (2017) menekankan lima elemen dasar yang seharusnya dirumuskan sebelum kebijakan itu dilaksanakan, diantaranya: lingkungan, input, sistem politik, output dan umpan balik. Hal tersebut berpengaruh pada dampak hasil kebijakan. 
POLITICON : Jurnal Ilmu Politik Vol.1 No.1 ; Hal 51 - 71

Website : http://journal.uinsgd.ac.id/index.php/politicon

ISSN : 2685-6670 ( Online )

Secara konsepsional, Dye mendefinisikan evaluasi kebijakan: "policy evaluation is learning about the consequences of public policy". Adapun definisi selanjutnya yang lebih kompleks adalah sebagai berikut:

"policy evaluation is the assesment of the overall effectiveness of a national program in meeting its objectives, or assesment of the relative effectiveness of two or more programs in meeting common objectives"

Mengacu definisi tersebut, evaluasi kebijakan merupakan suatu aktivitas untuk melakukan penilaian terhadap akibat atau dampak kebijakan program pemerintah. Pada studi kebijakan publik, istilah outputs dan outcomes memiliki makna yang berbeda secara mendasar, dan sebelumnya sudah di bahas pada bab tinjauan pustaka, sehingga dalam penggunaannya dibedakan antara "policy impact/ outcome dan policy output. "policy impact/outcome" adalah akibat dan konsekuensi yang ditimbulkan dengan dilaksanakannya suatu kebijakan. Dari pengertian tersebut, dampak kebijakan itu mengacu pada adanya perubahan-perubahan terjadi yang diakibatkan oleh implementasi kebijakan.Terdapat sejumlah dampak kebijakan yang perlu diperhatikan di dalam evaluasi kebijakan, yakni :

\section{The Impact On The Target Situations Or Group (Dampak Kebijakan terhadap Situasi atau Kelompok Target)}

Dampak kebijakan terhadap situasi atau kelompok target. Objek yang dimaksud sebagai sasaran kebijakan harus jelas. Misalnya masyarakat terkena dampak kebijakan pemberian ganti rugi (berdasarkan keriteria tertentu), sebagian penduduk yang ada di Kecamatan Darmaraja, Wado dan Jatigede, atau siapa saja yang menjadi sasaran. Efek yang dituju oleh kebijakan juga harus ditentukan. Jika berbagai kombinasi sasaran tersebut dijadikan fokus masa analisisnya menjadi lebih rumit karena prioritas harus diberikan kepada berbagai efek yang dimaksud. Disamping itu, perlu dipahami bahwa kebijakan kemungkinan membawa konsekuensi yang diinginkan atau tidak diinginkan. Masyarakat terkena dampak merasakan konsekuensi setelah penggenangan Waduk Jatigede, masyarakat banyak mengalami kehilangan mata pencaharian 
POLITICON : Jurnal Ilmu Politik Vol.1 No.1 ; Hal 51 - 71

Website : http://journal.uinsgd.ac.id/index.php/politicon

ISSN : 2685-6670 ( Online )

sebagai sumber rejekinya. Maka dari itu, banyak sekali masyarakat mengalami pergeseran sosial. Dengan kehilangan mata pencahariannya tidak sedikit masyarakat mengalami perubahan dari pola hidupnya.

\section{The Impact On Situations Or Group Other Than The Target (Dampak} Kebijakan terhadap Situasi atau Kelompok Lain Selain Situasi atau Kelompok Target)

Dampak kebijakan terhadap situasi atau kelompok lain selain situasi atau kelompok target. Hal ini disebut efek eksternalitas atau spillover, karena jumlah outcome kebijakan publik sangat berarti dipahami dengan istilah eksternalitas. Proses ganti rugi dalam pengadaan tanah telah melibatkan baik secara langsung maupun secara tidak langsung beberapa pihak. Misalnya: Pemerintah, Pemerintah Provinsi, Pemerintah Tingkat Kabupaten Sumedang, Pengusaha, Tokoh Masyarakat, Konsultan, Aktivis masyarakat, Masyarakat yang domisilinya berdampingan dengan OTD. Dalam hal ini, pemerintah mempunyai pengaruh cukup besar dalam proses pengadaan tanah, peraturan dan kebijakan anggaran yang mementukan adalah pihak pemerintah. Selain pemerintah, pengusaha khususnya pengusaha yang terlibat pada pembangunan Waduk Jatigede pun merasakan konsesuensunya, tidak jarang pembnagunan terhambat dikarenakan adanya penolakan dari warga. Tokoh masyarakat pun banyak melakukan konsolidasi yang mengatasnamakan masyarakat dalam proses penanganan dampak Waduk Jatigede, karena perjalanan pembangunan Waduk Jatigede cukup mengundang polemik sehingga banyak dibentuk organisasi atau aliansi warga OTD.

Its Impact On Future As Well As Immediate Conditions (Dampak Kebijakan terhadap Kondisi Sekarang dan Kondisi dimasa yang akan Datang)

Dampak kebijakan terhadap kondisi sekarang dan kondisi masa yang akan datang, dampak yang dirasakan langsung oleh masyarakat pada saat ini memang cukup signifikan sebelum adanya penggenangan. Masyarakat secara langsung belum merasakan manfaat cukup banyak dari pembangunan Waduk 
POLITICON : Jurnal Ilmu Politik Vol.1 No.1 ; Hal 51 - 71

Website : http://journal.uinsgd.ac.id/index.php/politicon

ISSN : 2685-6670 ( Online )

Jatigede, mengingat fasilitas yang dibangun belum secara optimal. Misalnya pembangunan jalan lingkar, belum adanya pembangunan jalan lingkar mengingat masih dalam proses sosialisasi pembebasan lahan.

Dampak sekarang belum memang belum dirasakan secara optimal oleh masyarakat, dikarenakan fasilitas lain yang menunjang manfaat jatigede belum terselesaikan misalnya jalan lingkar, yang berdampak pada sektor wisata belum dirasakan secara maksimal karena masyarakat mengalami kesulitan, pembangkit listrik belum dapat dirasakan dikarenakan pihak PLN masih pada tahap pembebasan lahan. Dampak dimasa yang akan datang masyarakat bisa secara langsung merasakan manfaat adanya Waduk Jatigede diantaranya:

1. Menyuplai kebutuhan irigasi untuk 90.000 ha. untuk daerah Majalengka, Cirebon dan Indramayu

2. Pembangkit listrik tenaga air dengan kapasitas $110 \mathrm{MW}$

3. Menyuplai kebutuhan air baku sebesar 3.500 liter per detik untuk daerah Sumedang, Majalengka, Cirebon dan Indramayu.

4. Pengendali banjir untuk luas 14.000 ha

5. Menciptakan sektor wisata daerah Kabupaten Sumedang untuk perkembangan ekonomi dan kesejahteraan masyarakat

Its Direct Cost, In Term Of Resources Devote To The Program (Biaya Langsung Kebijakan, Dalam Bentuk Sumber Dana yang Digunakan dalam Pelaksanaan Program)

Biaya langsung kebijakan, dalam bentuk sumber dana yang digunakan dalam pelaksanaan program. Dalam kaitan ini sumber anggaran yang digunakan adalah yang bersumber dari nasional dan internasional. Yang bersumber dari nasional berupa pendanaan untuk pelaksanaan kegiatan pemberian uang tunai untuk rumah pengganti dan pemberian uang santunan bersumber dari Anggaran Pendapatan Belanja Negara, dalam hal ini Anggaran Pendapatan dan Belanja Negara Kementerian Pekerjaan Umum dan Perumahan Rakyat. Sedangkan yang bersumber dari internasional adalah 
POLITICON : Jurnal Ilmu Politik Vol.1 No.1 ; Hal 51 - 71

Website : http://journal.uinsgd.ac.id/index.php/politicon

ISSN : 2685-6670 ( Online )

pinjaman dari pemerintah China. Pelaksanaan program Waduk Jatigede menghabiskan anggaran dari tahun 1983-2015 mencapai 467 juta US dolar.

Its Indirect Cost, Including Loss Of Opportunities To Do Other Things (Biaya Tidak Langsung Kebijakan, Mencakup Kehilangan Peluang Melakukan Kegiatan Lain)

Biaya tidak langsung kebijakan, yang mencakup kehilangan peluang melakukan kegiatan-kegiatan lainnya. Biaya tersebut sering tidak diperhitungkan dalam melakukan evaluasi kebijakan publik karena sebagian tidak dapat dikuantifikasi. Hal ini berkaitan dengan kebutuhan fasilitas umum baru bagi OTD dikarenakan fasilitas umum yang dulu hilang. Dengan adanya pembangunan Waduk Jatigede berapa banyak fasilitas umum seperti sekolah, posyandu, dan lain sebagainya hilang, sehingga masyarakat mengalami dampak dari hilangnya fasilitas umum tersebut. Dengan hilangnya fasilitas umum, menuntut harus adanya pembangunan kembali akan fasilitas tersebut. Belum optimalnya pembangunan fasilitas umum di daerah pindahan OTD, sehingga banyak masyarakat yang mengeluhkan kaitan ini.

Analisis Peneliti Mengenai Inefisiensi dalam Pengadaan Tanah Untuk Kepentingan Umum (Studi Kasus Pembangunan Waduk Jatigede di Kabupaten Sumedang)

Berdasarkan uraian bab sebelumnya, peneliti memandang terjadinya inefisiensi dalam proses pengadaan tanah untuk pembangunan Waduk Jatigede. Hal tersebut dilihat dari aspek regulasi, waktu dan biaya. Berikut tinjauan dari beberapa aspek:

\section{Tinjauan Regulasi}

Pengadaan tanah selalu menjadi topik pembahasan yang cukup menarik dan tidak lekang oleh waktu. Regulasi tentang pengadaan tanah selalu berkembang dan mengalami perubahan setiap waktunya. Pengadaan tanah untuk Waduk Jatigede dari tahun 1983 sampai dengan tahun 2015 mengalami beberapa perubahan regulasi. 
POLITICON : Jurnal Ilmu Politik Vol.1 No.1 ; Hal 51 - 71

Website : http://journal.uinsgd.ac.id/index.php/politicon

ISSN : 2685-6670 ( Online )

\section{Tinjauan Waktu}

Pembebasan tanah untuk pembangunan Waduk Jatigede memakan waktu cukup panjang dari tahun 1983-2015, selama 32 tahun waktu yang dihabiskan. Hal ini bukan tanpa alasan, berdasarkan beberapa keterangan pihak panitia menegaskan adanya perubahan skala prioritas dari pembangunan nasional. Waduk Jatigede adalah program nasional, program kerja presiden pada saat itu sangat berpengaruh pada keberlanjutan pembangunan. Mengingat pembangunan Waduk Jatigede mengalami beberapa kali momentum politik dan pergantian presiden. Selain itu, berlaturlarutnya waktu yang dihabiskan dikarenakan biaya yang dikeluarkan terbatas dan harus menyesuaikan pada ketersediaan anggaran yang ada, baik dengan APBN atau sumber lain.

\section{Tinjauan Biaya}

Tabel 3. Biaya Pengadaan Tanah

\begin{tabular}{|c|c|c|c|c|c|}
\hline Tahun & $\begin{array}{l}\text { Luas } \\
\text { (Ha) }\end{array}$ & Nilai (Rp) & $\begin{array}{l}\text { Nilai } \\
\text { Emas/g } \\
\text { ram } \\
\text { (Rp) }\end{array}$ & Nilai (Rp)/ Ha & Per-meter \\
\hline 1 & 2 & 3 & 4 & $\begin{array}{l}5 \\
(3: 2)\end{array}$ & $\begin{array}{l}6 \\
(5: 1000)\end{array}$ \\
\hline $\begin{array}{l}1982 / 198 \\
3 \mathrm{~S} / \mathrm{D} \\
1985 / 198 \\
6\end{array}$ & $\begin{array}{l}2101.6 \\
5\end{array}$ & 18.721.892.891,00 & 12.000 & $\begin{array}{l}8.908 .187,800537 \\
6\end{array}$ & $8.908,19$ \\
\hline $\begin{array}{l}1994 / 199 \\
5\end{array}$ & 54.91 & $3.857 .662 .034,00$ & 24.000 & $\begin{array}{l}70.254 .271,24385 \\
3\end{array}$ & $70.254,28$ \\
\hline $\begin{array}{l}1995- \\
1996 \\
\end{array}$ & 36.36 & $10.816 .989 .277,00$ & 26.000 & $\begin{array}{l}297.496 .954,8129 \\
8\end{array}$ & $297.496,96$ \\
\hline $\begin{array}{l}1996 / 199 \\
7\end{array}$ & $\begin{array}{l}146.85 \\
2\end{array}$ & $14.517 .609 .900,00$ & 27.000 & $\begin{array}{l}98.858 .782,31144 \\
2\end{array}$ & 98.858 .79 \\
\hline $\begin{array}{l}1997 / 199 \\
8\end{array}$ & 84.45 & $9.446 .594 .576,00$ & 75.000 & $\begin{array}{l}111.860 .208 .1231 \\
4\end{array}$ & $111.860,12$ \\
\hline $\begin{array}{l}1998 / 199 \\
9\end{array}$ & 32.54 & $8.131 .907 .133,00$ & 66.280 & $\begin{array}{l}249.904 .951,8438 \\
8\end{array}$ & $294.904,96$ \\
\hline $\begin{array}{l}1999 / 200 \\
0\end{array}$ & $\begin{array}{l}\text { Tidak } \\
\text { ada } \\
\text { data }\end{array}$ & $3.272 .882 .801,00$ & 71.875 & Tidak ada data & $\begin{array}{l}\text { Tidak ada } \\
\text { data }\end{array}$ \\
\hline 2001 & $\begin{array}{l}\text { Tidak } \\
\text { ada } \\
\text { data }\end{array}$ & $628.415 .000,00$ & 80.000 & Tidak ada data & $\begin{array}{l}\text { Tidak ada } \\
\text { data }\end{array}$ \\
\hline 2004 & 72.95 & $20.705 .946 .020,00$ & 97.500 & $\begin{array}{l}283.837 .505,4146 \\
6\end{array}$ & $283.837,50$ \\
\hline
\end{tabular}

POLITICON VOL.1 No.1 Juli 2019 
POLITICON : Jurnal Ilmu Politik Vol.1 No.1 ; Hal 51 - 71

Website : http://journal.uinsgd.ac.id/index.php/politicon

ISSN : 2685-6670 ( Online )

\begin{tabular}{|c|c|c|c|c|c|}
\hline 2005 & 99.87 & $37.641 .396 .710,00$ & 147.257 & $\begin{array}{l}376.903 .942,2248 \\
9\end{array}$ & $376.903,94$ \\
\hline 2006 & 352.78 & $\begin{array}{l}142.460 .658 .228,0 \\
0\end{array}$ & 182.500 & $\begin{array}{l}403.822 .944,1238 \\
1\end{array}$ & $403.822,94$ \\
\hline 2007 & 142.68 & $\begin{array}{l}137.686 .503 .649,0 \\
0\end{array}$ & 200.046 & $\begin{array}{l}965.002 .128,1819 \\
4\end{array}$ & $965.002,12$ \\
\hline 2008 & 258.02 & $\begin{array}{l}127.056 .026 .840,0 \\
0\end{array}$ & 280.046 & $\begin{array}{l}492.427 .047,6707 \\
2\end{array}$ & $492.427,04$ \\
\hline 2009 & 58.18 & $\begin{array}{l}105.883 .453 .832,0 \\
0\end{array}$ & 296.534 & $\begin{array}{l}1.819 .928 .735,51 \\
04\end{array}$ & $1.819 .928,73$ \\
\hline 2010 & 208.5 & $93.693 .986 .495,00$ & 350.000 & $449.371 .637,8657$ & $449.371,63$ \\
\hline 2011 & 325.29 & 73.095.361.644,00 & 400.000 & $\begin{array}{l}224.708 .296,1173 \\
1\end{array}$ & $224.708,30$ \\
\hline 2012 & 72.61 & $6.873 .208 .500,00$ & 532.000 & $\begin{array}{l}94.659 .254,92356 \\
4\end{array}$ & $94.659,26$ \\
\hline 2013 & 11.39 & $41.503 .370 .868,00$ & 524.000 & $\begin{array}{l}3.643 .842 .920,80 \\
77\end{array}$ & $3.643 .842,92$ \\
\hline 2014 & 0.31 & 4.767.718.822,00 & 483.000 & $\begin{array}{l}15.379 .738 .135,4 \\
83\end{array}$ & $\begin{array}{l}15.379 .738,1 \\
3\end{array}$ \\
\hline 2015 & 17.0 & $3.490 .424 .273,00$ & 489.000 & $\begin{array}{l}205.319 .074,8823 \\
5\end{array}$ & $205.319,08$ \\
\hline 2016 & 0.65 & $5.608 .529 .800,00$ & 506.600 & $\begin{array}{l}8.628 .507 .384,61 \\
53\end{array}$ & $8.628 .507,39$ \\
\hline Jumlah & $\begin{array}{l}4.076 . \\
992\end{array}$ & 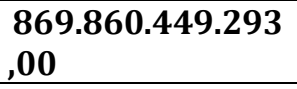 & & & \\
\hline
\end{tabular}

Sumber: Data PPK Pertanahan Satker Jatigede yang diolah peneliti, Desember 2017

Berdasarkan tabel diatas dapat dilihat bahwa uang pengganti atas hak tanah dan bangunan untuk warga masyarakat pada saat itu dianggap sudah sepadan. Hal ini terlihat dari nominal yang diberikan pemerintah kepada masyarakat dengan per-meter jika dikonversikan dengan harga emas pada saat itu. Besaran uang yang diterima oleh masyarakat sudah mencakup uang ganti rugi atas bangunan dan tanaman.

Tabel 4. Hasil Konversi dengan Nilai Jual Emas

\begin{tabular}{|c|c|c|c|c|}
\hline Tahun & $\begin{array}{c}\text { Luas } \\
\text { (Ha) }\end{array}$ & Nilai (Rp) & $\begin{array}{r}\text { Nilai } \\
\text { Emas/gram } \\
\text { (Rp) }\end{array}$ & Jumlah \\
\hline $\mathbf{1}$ & $\mathbf{2}$ & $\mathbf{3}$ & $\mathbf{4}$ & $\mathbf{5}(\mathbf{3 : 4 )}$ \\
\hline $\begin{array}{l}1982 / 1983 \\
\text { S/D }\end{array}$ & 2101.65 & $18.721 .892 .891,00$ & 12.000 & $1.560 .157,741$ \\
\hline
\end{tabular}

POLITICON VOL.1 No.1 Juli 2019 
POLITICON : Jurnal Ilmu Politik Vol.1 No.1 ; Hal 51 - 71

Website : http://journal.uinsgd.ac.id/index.php/politicon

ISSN : 2685-6670 ( Online )

\begin{tabular}{|c|c|c|c|c|}
\hline $1985 / 1986$ & & & & \\
\hline $1994 / 1995$ & 54.91 & $3.857 .662 .034,00$ & 24.000 & $160.735,9181$ \\
\hline 1995-1996 & 36.36 & $10.816 .989 .277,00$ & 26.000 & $416.038,0491$ \\
\hline $1996 / 1997$ & 146.852 & $14.517 .609 .900,00$ & 27.000 & $537.689,2556$ \\
\hline $1997 / 1998$ & 84.45 & $9.446 .594 .576,00$ & 75.000 & $125.954,5943$ \\
\hline $1998 / 1999$ & 32.54 & $8.131 .907 .133,00$ & 66.280 & $122.690,2102$ \\
\hline $1999 / 2000$ & $\begin{array}{l}\text { Tidak ada } \\
\text { data }\end{array}$ & $3.272 .882 .801,00$ & 71.875 & $45.535,76071$ \\
\hline 2001 & $\begin{array}{l}\text { Tidak ada } \\
\text { data }\end{array}$ & $628.415 .000,00$ & 80.000 & $7.855,1875$ \\
\hline 2004 & 72.95 & $20.705 .946 .020,00$ & 97.500 & $212.368,6771$ \\
\hline 2005 & 99.87 & $37.641 .396 .710,00$ & 147.257 & $255.617,0281$ \\
\hline 2006 & 352.78 & $142.460 .658 .228,00$ & 182.500 & $780.606,3465$ \\
\hline 2007 & 142.68 & $137.686 .503 .649,00$ & 200.046 & $688.274,2152$ \\
\hline 2008 & 258.02 & $127.056 .026 .840,00$ & 280.046 & $453.696,9885$ \\
\hline 2009 & 58.18 & $105.883 .453 .832,00$ & 296.534 & $357.070,1971$ \\
\hline 2010 & 208.5 & $93.693 .986 .495,00$ & 350.000 & $267.697,1043$ \\
\hline 2011 & 325.29 & $73.095 .361 .644,00$ & 400.000 & $182.738,4041$ \\
\hline 2012 & 72.61 & $6.873 .208 .500,00$ & 532.000 & $12.919,56485$ \\
\hline 2013 & 11.39 & $41.503 .370 .868,00$ & 524.000 & $79.204,90624$ \\
\hline 2014 & 0.31 & $4.767 .718 .822,00$ & 483.000 & $9.871,053462$ \\
\hline 2015 & 17.0 & $3.490 .424 .273,00$ & 489.000 & $7.137,881949$ \\
\hline 2016 & 0.65 & $5.608 .529 .800,00$ & 506.600 & $11.070,92341$ \\
\hline Jumlah & 146852 & $869.860 .539 .293,00$ & & $6.294 .930,007$ \\
\hline
\end{tabular}

Sumber: Data PPK Pertanahan Satker Jatigede yang diolah peneliti, Desember 2017

Berdasarkan data pada tabel diatas adalah hasil konversi jumlah uang yang dikeluarkan untuk pengadaan tanah kemudian dikonversikan dengan harga emas. Jumlahnya adalah Rp. 6.294.930,007. Jumlah hasil konversi dikalikan dengan harga emas pada saat ini sebesar Rp. 625.000 yang hasilnya $6.294 .930,007 * 625.000=3.934 .331 .254 .375$. Jika dilihat dari jumlah yang dikeluarkan untuk biaya pengadaan tanah sebesar Rp.3.934.331.254.375 peneliti menilai cukup besar biaya yang dikeluarkan. Disamping itu semua, pemerintah pun harus mengeluarkan uang selain pengadaan tanah yaitu biaya penanganan dampak waduk Jatigede sebesar Rp.775.663.535.034. penanganan dampak adalah bagian dari proses pengadaan tanah, dikarenakan adanya dampak pembangunan Waduk Jatigede dikarenakan pada saat itu bermunculan masalah berkaitan pengadaan tanah. Misalnya,

POLITICON VOL.1 No.1 Juli 2019 
POLITICON : Jurnal Ilmu Politik Vol.1 No.1 ; Hal 51 - 71

Website : http://journal.uinsgd.ac.id/index.php/politicon

ISSN : 2685-6670 ( Online )

banyak masyarakat yang melakukan komplen, seharusnya pada saat pengadaan tanah sudah selesai.

\section{SIMPULAN}

Simpulan penelitian yang berjudul Inefisiensi Pengadaan Tanah Untuk Kepentingan Umum (Studi Kasus pada Pembangunan Waduk Jatigede di Kabupaten Sumedang) sebagai berikut:

1. Peneliti menyimpulkan adanya inefisiensi dalam proses pengadaan tanah dengan menggunakan pendekatan kriteria administrative operability. Sangat berpengaruh pada tidak efektifnya suatu program dikarenakan tujuan yang dicapai tidak secara tepat sesuai dengan target waktu dan biaya, hal ini berdasarkan dengan penilaian berdasarkan kriteria ini adalah persoalan kewenangan (authority), komitmen institusi (institutional commitment), kemampuan (capability), dukungan organisasi (organizational support).

2. Dari pendekatan kriteria administrative operability tidak optimal, berpengaruh pada tidak efektifnya proses pengadaan tanah untuk pembangunan Waduk Jatigede di Kabupaten Sumedang. Diketahui dari empat batasan kriteria administrative operability terjadi inefisiensi yang berimplikasi pada aspek regulasi, waktu dan biaya. Dengan begitu sangat berpengaruh pada dampak kebijakan pengadaan tanah untuk pembangunan Waduk Jatigede. Diantaranya: The impact on the target situations or group; The impact on situations or groups other than the targer (spillover effect); Its impact on future as well immediate conditions; Ist direct cost, in term of resources devote to the program; Ist indirect cost, including loss of opportunities to do other things tidak tercapai dengan maksimal..

\section{DAFTAR PUSTAKA}

Abdurahman. (1995). Masalah Pencabutan Hak-hak Atas Tanah, Pembebasan Tanah dan Pengadaan Tanah Bagi Pelaksanaan Pembangunan Untuk Kepentingan Umum. Bandung: Citra Aditya Bakti.

Abdurahman. (1991). Masalah Pencabutan Hak-Hak atas Tanah dan Pembebasan Tanah di Indonesia. Bandung: Citra Abadi Bakti. 
POLITICON : Jurnal Ilmu Politik Vol.1 No.1 ; Hal 51 - 71

Website : http://journal.uinsgd.ac.id/index.php/politicon

ISSN : 2685-6670 ( Online )

Abidin, S. Z. (2006). Kebijakan Publik. Edisi Revisi Cetakan Katiga. Jakarta: Penerbit Suara Bebas.

Anderson, J. (1979). Public Policy. New York: Holt Rinehart and Winston.

Buchari. A., Sumaryana. A., dan Novi Andari. R. (2017). An Alternative Model Of Child Sexualabuse Handling Policyn Indonesia. Sosiohumaniora, Volume 19 No. 3 Nopember 2017:260-267.

Dunn, W. (2003). Analisis Kebijakan Publik. Yogyakarta: Gadjah Mada University Press.

Dunn, W. (2003). Public Policy Analysis: An Introduction Second Edition. Englewood Cliffs, NJ: Prentice-Hall, Inc.

Dye, T. (2005). Understanding Public Policy. Pearson Pretice Hall: Eleventh Edition, New Jersey.

Harsono , B. (2008). Hukum Agraria Indonesia : Sejarah Pembentukkan Undangundang Pokok Agraria, Isi dan Pelaksanaannya . Jakarta: Djambatan.

Harsono , B. (2008). Hukum Agraria Indonesia: Sejarah Pembentukan Undangundang Pokok Agraria, Isi dan Pelaksanaannya . Jakarta: Djambatan.

Huberman, M. B. (1992). Analisis data kualitatif: Buku sumber tentang metodemetode baru. Penerjemah : Tjetjep Rohendi Rohidi. Jakarta: Universitas Press.

Journal, T. G. (2012). Undang-undang Pengadaan Tanah Baru Efektif 2013 . The Globe Journal.

Mia Putu Rahmawati (2012). Kewenangan Negara sebagai Pengatur, Perencana, Pelaksana dan Pengawas Pengelolaan, Penggunaan dan Pemanfaatan SDA Nasional.

Moh. Fahmi Bahrudin (2015). Kekuasaan Pemerintah Daerah dalam Pembangunan untuk Kepentingan Umum.

Nugroho, R. (2009). Pengantar Analisis Kebijakan, Terjemahan oleh: Samodra Wibawa, dkk. Penyunting: Muhadjir Darwin. Yogyakarta: Gajah Mada University Press.

Parsons, W. (2006). Public Policy: Pengantar Teori dan Praktik Analisis Kebijakan, alih Bahasa Oleh Tri Wibowo B. S. Jakarta: Kencana. 
POLITICON : Jurnal Ilmu Politik Vol.1 No.1 ; Hal 51 - 71

Website : http://journal.uinsgd.ac.id/index.php/politicon ISSN : 2685-6670 ( Online )

Pasolong, H. (2012). Metode Penelitian Administrasi Publik. Bandung: Alfabeta.

Patton, M. (1997). Utilization Focused Evaluation:The New Century Text. Sage Publications.

Rini Mulyanti (2013). Sengketa Tanah dalam Proses Ganti Rugi Pengadaan Tanah.

Vedung, E. (2005). Public Policy and Program Evaluation. New Brunswik: New Jersey: Transaction Publishers.

Wibawa, S. (1994). Evaluasi kebijakan Publik. Jakarta: PT. Raja Grafindo Persada.

Winarno, B. (2002). Teori dan Proses Kebijakan Publik. Yogyakarta: Media Pressindo.

\section{Dokumen-Dokumen:}

Undang-Undang Nomor 2 Tahun 2012 Tentang Pengadaan Tanah Bagi Pembangunan Untuk Kepentingan Umum, Penjelasan Umum.

Perpres No. 1 Tahun 2015 tentang Pembayaran Ganti Rugi terhadap Warga Terkena Dampak Pembangunan Waduk Jatigede. 